\title{
STRENGTHENING THE RURAL ENTREPRENEURSHIP IN THE REPUBLIC OF MACEDONIA
}

Martina Krstevska", Inspection Council Skopje, Republic of Macedonia
Nada Trenceva, Municipality of City of Kavadarci, Republic of Macedonia

Abstract: Entrepreneurship is seen as a main driving force for the economic development of the Republic of Macedonia in general and particularly for the development of the rural areas. The purpose of this paper is to present the real situation with the rural entrepreneurship in the Republic of Macedonia by using the survey, statistical method and method of deduction.

The studies in this paper point to conclusion that the rural areas in the Republic of Macedonia are characterized by great abandonment, loneliness, a decade trend of migration and high unattractiveness on the part of entrepreneurs to conduct business in the rural areas.

Based on the survey of the entrepreneurs' attitude to start business in rural areas, this paper provides recommendation for outlining future policies, measures and instruments that will facilitate the creation of stimulating sustainable rural entrepreneurship in the Republic of Macedonia.

Key words: rural entrepreneurship, policies, measures, instruments, recommendations

JEL classification: $M 13, O 18, R 0$

\section{JAČANJE RURALNOG PREDUZETNIŠTVA U REPUBLICI MAKEDONIJI}

Sažetak: Preduzetništvo se vidi kao glavna pokretačka snaga za ekonomski razvoj u Republici Makedoniji u celini, a naročito za razvoj ruralnih područja. Cilj ovog rada je da pomoću ankete, statističkog metoda i metoda dedukcije predstavi realnu situaciju ruralnog preduzetništva u Republici Makedoniji. Studije u ovom radu ukazuju na zaključak da ruralna područja u Republici Makedoniji karakteriše velika napuštenost, usamljenost, decenijski trend migracije i visoke neprivlačnosti od strane preduzetnika za obavljanje poslova u ruralnim područjima.

*martina_krstevska@yahoo.com 
$\mathrm{Na}$ osnovu ankete o preduzetničkom stavu da započnu poslovanje u ruralnim područjima, u ovom radu daju se preporuke za buduće politike, mere i instrumente koji će omogućiti stvaranje stimulativnog održivog ruralnog preduzetništva u Republici Makedoniji.

Ključne reči: ruralno preduzetništvo, politike, mere, instrumenti, preporuke.

\section{INTRODUCTION}

The importance of entrepreneurship as a factor in accelerating the economic growth and development has been remarked on European level a long ago. The entrepreneurship is a key component of the European Union 2020: Strategy for smart, sustainable and inclusive development.

Entrepreneurship is seen as the most important fundamental characteristics for the regional development. For this purpose, a lot of government programs are created aimed at developing entrepreneurship in rural areas and thus enabling economic and employment growth in these areas.

Rural areas are very often unattractive to entrepreneurs due to their geographic location that distracts the entrepreneurs and the qualified work force as well (Dabson, 2001).

Besides the geographical distance the typical characteristics of the rural areas are: poor transport infrastructure, small size of the local markets, unskilled work force, lack of information and financial resources (Smallbone, \& Welter, 2006).

Rural development and rural entrepreneurship is already incorporated in Macedonia's national strategies, but entrepreneurs in Macedonia face a number of challenges that the rural areas make less attractive when compared to urban ones. Rural areas in the Republic of Macedonia are mainly characterized by low population density, inaccessibility, internal and external isolation, underdeveloped basic infrastructure and so on. An additional aggravating factor for rural entrepreneurs is a small market for products and services, limited access to financial resources, local labor force that does not suit the entrepreneurs' needs, as young and educated people generally leave these places.

However, despite all these limiting factors for the development of rural entrepreneurship in Macedonia, it is important to emphasize that rural areas in Macedonia possess rich natural resources which the innovative entrepreneurs can turn into products and services with great added value.

Properly designed strategy, policy measures and instruments that support rural entrepreneurship can stimulate and encourage rural entrepreneurs to take risks 
and start initiative, first using the given natural resources, ensuring a profit for themselves and their family on the one hand, and creating products and valueadded services on the other, and thus creating vitality in rural areas.

The improved quality of life in rural areas will increase the attractiveness of these areas and in the long run it may start a trend of migration from urban to rural areas, just according to this trend in Western European countries. This trend may balance the territorial distribution of the population in the Republic of Macedonia, so the urban city centers can rationalize the sizeable layer of population and the rural areas may revive and participate with great contribution to the country's GDP. Following the example of European countries, it may lead to a change in lifestyle of the population in Macedonia, which is more and more attractive and popular for the European citizens.

\section{RURAL POPULATION IN THE REPUBLIC OF MACEDONIA - ABANDONMENT OF THE RURAL AREAS}

According to the Law on Agriculture and Rural Development, rural areas in Macedonia are defined as "the area of the municipality in the Republic Macedonia in which any inhabited place has no more than 30000 inhabitants according to the national census of population and housing in the country or population density less than or equal to 150 inhabitants per kilometer square area of the municipality" (Law on Agriculture and Rural development, 2010, Article 63, paragraph 1).

As shown in Picture 1, since the sixties of the last century until today there is a typical trend of significant decline in the rural population in Macedonia as a percentage of the total population, from $66 \%$ in 1960 to $43 \%$ in 2015 . Due to the lack of basic conditions of subsistence in rural areas, ranging from poor infrastructure of rural areas - bad roads, some areas without access to electricity, without sewer, the unemployment of rural population and low income from agriculture, to the lack of basic education and health services, rural areas in Macedonia are characterized by abandonment, loneliness, inactivity. 


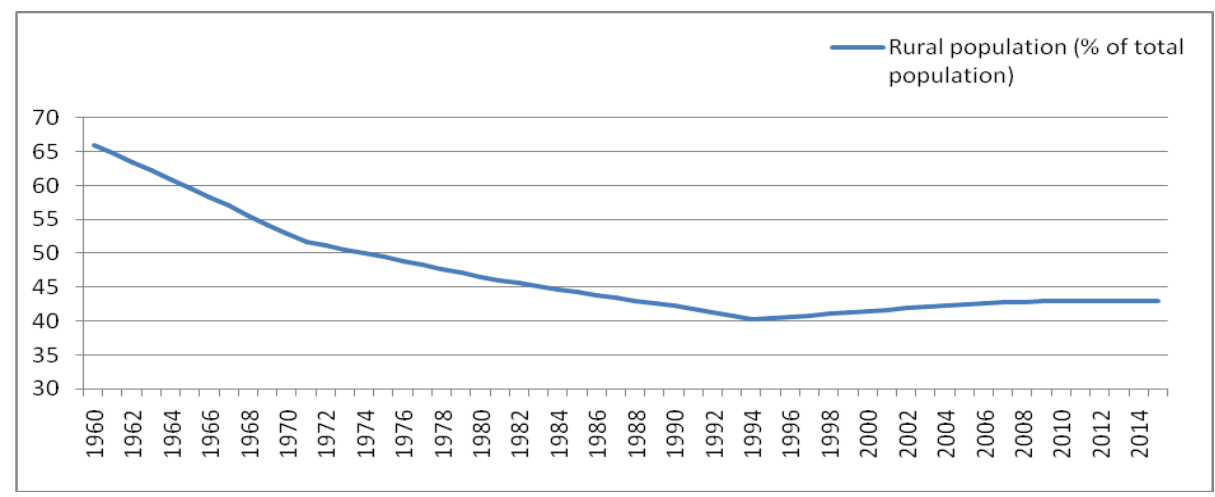

Picture 1. Rural population in the Republic of Macedonia during the years (\% of total population)

Note. Retrieved from World Bank, Rural population (\% of total population) (2016) http://data. worldbank.org/indicator/SP.RUR.TOTL.ZS end=2015\&locations=MK\&start $=1960 \&$ view $=$ chart

The migration of rural population in Macedonia is a trend that is characteristic since the second half of the twentieth century but that occurs with different intensity and directions. At some time migration largely moved on route ruralurban areas, while in other time period the external migration has been enhanced.

The process of migration from rural to urban areas has reached its peak in the sixties and seventies of the twentieth century. The strong intensity of this process is a result of intensive socio-economic development. Migration process from rural to urban areas stagnated in eighties of the twentieth century, but in that period the migration process was not stopped, but the migration was external when mostly rural people have migrated abroad.

In the last two decades there has been a little migration of population from rural areas to urban. Namely, the data of the State Statistical Office show that in the Republic of Macedonia over the last ten years, from 2005 to 2015, a total of 20,763 people migrate from rural to urban areas. $51 \%$ of the total is aged from 15 to 29 years, while $42 \%$ were aged from 30 to 64 years (State Statistical Office, 2016).

However, this is mainly due to the previous huge migration and abandonment of the rural areas (internal migration, rural-urban and external migration, ruralabroad) as well as the aging of the population in rural areas and the reduction of the percentage of growth of rural population. As shown in Picture 2, the World Bank data says that in Macedonia in the period from 2006 to 2015 there is a trend of steady decrease in the percentage of growth of the rural population and increase in the percentage of urban population growth. 


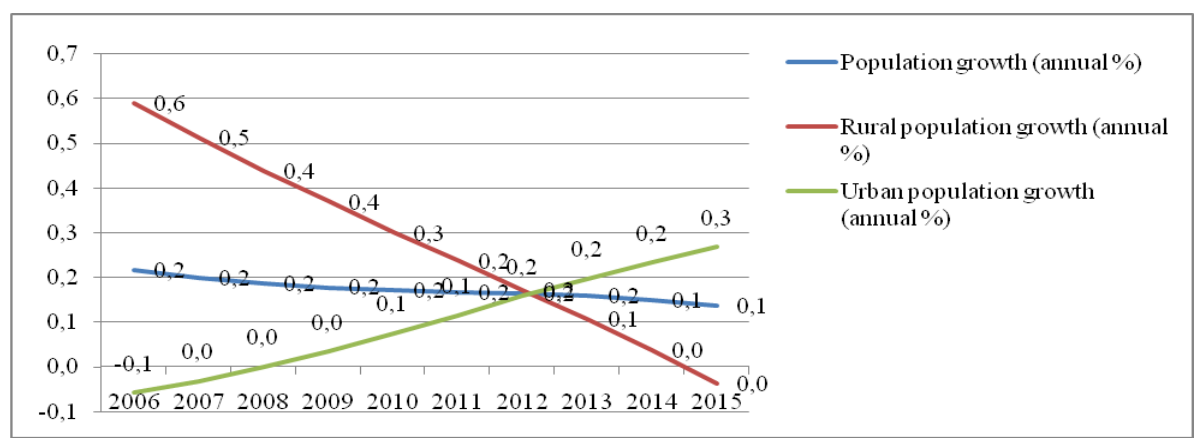

Picture 2. Rural population growth in the Republic of Macedonia (annual \%)

Note. Retrieved from World Bank, Population growth, Rural population growth, Urban population growth (\%of total population) (2016) http://databank.worldbank.org/data/reports.aspx?source=2\&series

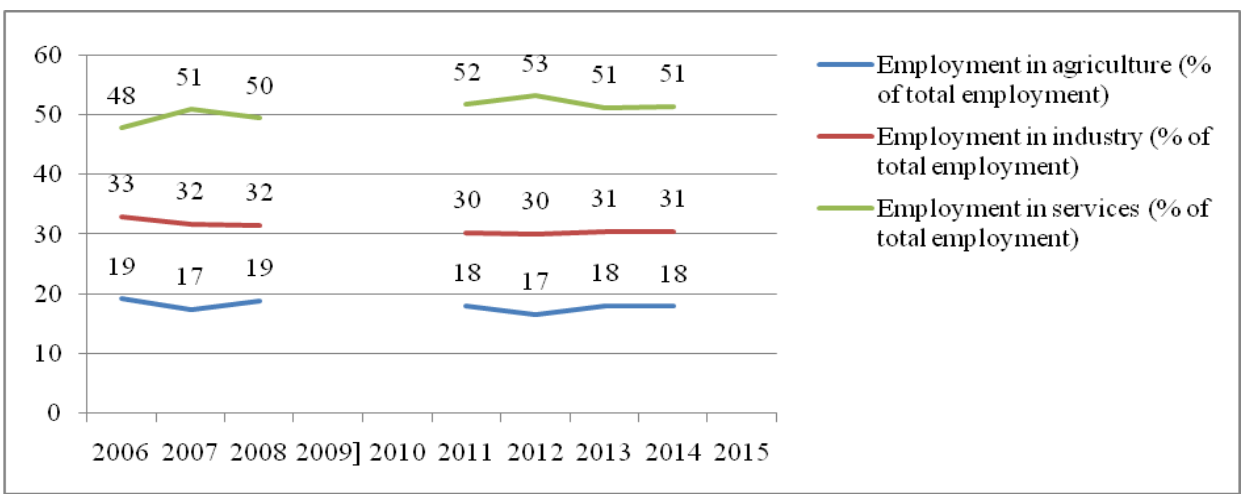

Picture 3. Employment per sectors in the Republic of Macedonia (\% of Total employment)

Note: Retrieved from World Bank, Population growth, Rural population growth, Urban population growth (\% of total population) (2016). http://databank.worldbank.org/data/reports.aspx?source=2\&series

While it is said that the agriculture is the mainstay of the economy of the Republic of Macedonia, the agriculture in the Republic of Macedonia is increasingly abandoned. The Picture 3 shows that in 2014, employment in agriculture amounted to $18 \%$, industry $31 \%$, while in the service sector $51 \%$.

\section{RESEARCH METHODOLOGY}


A various scientific methods were used in this paper to present the real situation with rural entrepreneurship in the Republic of Macedonia as follows:

- Statistical method, using graphical and tabular data presentation;

- Method of deduction (from the general situation in rural areas in the Republic of Macedonia conclusions are derived about the reasons for such a situation and

- Quantitative method of research, which is a major method in this paper where the data are collected on a standardized questionnaire which measures the reaction of respondents to the specified number of questions, which facilitates the statistical analysis and comparisons and allows to generalize findings.

This paper, through a survey of a representative sample that included 40 entrepreneurs of small and medium enterprises (according to the criteria, number of employees, value of operating assets and annual revenues are defined as small and medium enterprises) analyze the entrepreneurs' attitude in terms of starting a business in rural areas. The aim is to give a realistic picture of entrepreneurial activity in the Republic of Macedonia and to provide a critical review of the policies, measures and instruments that exist de jure, but de facto have almost no effect in encouraging entrepreneurs to start a business in rural areas.

The survey, which is attached to this paper as an appendix contains 10 questions with up to 3 variants of answers. In the survey there are questions that can give a broader response depending on the desire of the interviewed person. The survey contains information on the entrepreneurial attitude about rural areas, institutional and financial support for rural entrepreneurs etc.

\section{RESULTS OF THE RESEARCH}

In order to create an entrepreneurial society, especially for the development of rural entrepreneurship, there is a necessity for integral development of the overall environment in rural areas in order to encourage entrepreneurs to take economic activity and to start a business in rural areas (OECD, 2000).

Besides the basic precondition that rural areas need to meet some requirements in order to encourage entrepreneurs to start business, such as good infrastructure connections with road transport, water, sewerage, available electricity, there are also other important ones that are, in most cases, crucial in the decision to start a business in these areas.

According to the processed data we came to these findings: 
1. $70 \%$ of entrepreneurs said they prefer to start entrepreneurial activity in urban areas, while only $30 \%$ of entrepreneurs said they would start their own business in some rural areas.

The analysis leads to the conclusion that when making decision and choice to start an entrepreneurial activity between rural and urban areas a lot of factors influence the decision ranging from infrastructure, the factors of production, and institutional support, to the awareness of entrepreneurs about the profitability of rural businesses. The sum of all these factors still make rural areas in Macedonia unattractive for entrepreneurs when making a choice between entrepreneurial activity in a rural or urban area.

2. When asked what are the most common businesses in rural areas in Macedonia most entrepreneurs responded agriculture and tourism.

These responses go side by side with the fact that rural areas in Macedonia are highly dependent on agriculture. The fact that $76.4 \%$ of the farms are located in predominantly rural regions shows that almost all farms and agricultural labor are located in rural areas in Macedonia (Ministry of Agriculture, Forestry and Water Economy, 2015).

The indication of entrepreneurs for rural tourism affirm the strengthening entrepreneurs awareness about the potential for development of rural tourism in Macedonia. Still, at the moment, rural tourism in Macedonia is generating a very small proportion of the national income from tourism.

3. As more important decisive factors that influence the entrepreneurs' decision to start businesses in rural areas, entrepreneurs specify: the infrastructure, road, water supply, sewage, electricity, the size of the market for products and services etc.

Taking into account the fact that some rural areas in Macedonia are not passable, especially the remote high mountain ones, the infrastructure is a serious obstacle that discourages entrepreneurs to undertake entrepreneurial activity in these areas. This is due to the insufficient investment and maintenance of the rural infrastructure and at the same time it poses a serious threat to retain the local population and attract entrepreneurial activity in these areas.

4. When asked "if entrepreneurs start a business in a rural area would the local people be qualified to be employed", $77 \%$ of entrepreneurs answered with "no", while $23 \%$ answered affirmatively.

As the availability of the overall services in rural areas is very unsatisfactory, so is the availability of the educational services. Slightly better is the situation with the availability of primary schools, but not with secondary schools that are SCHOOL OF BUSINESS, 2/2016, $14-28$ 
mostly located in urban areas. The distance has a huge negative impact on the education of the rural population and often is a reason for internal migration to urban areas.

5. The analysis shows that $96 \%$ of the entrepreneurs believe that Macedonia has good local natural resources that would be sufficient for the development of rural entrepreneurship.

The State Statistical Office data show that in $201450.1 \%$ of the total land area in Macedonia is utilized agricultural area, $44.3 \%$ is forest, while $4 \%$ is water and other surfaces. The arable land presents $40 \%$ of the total agricultural land, while $81 \%$ of the total arable land belongs to fields and gardens, $3 \%$ orchards, $4 \%$ vineyards and $11 \%$ meadows. The pastures present $60 \%$ of the total land in Macedonia (Ministry of Agriculture, Forestry and Water Management, 2015).

With properly designed policies, measures and instruments, institutional support, increased investment in physical infrastructure, policy makers may increase the attractiveness of rural entrepreneurship with regard to the use of the natural resources that rural areas possess.

6. The question of whether you think that business in the rural area will be more successful if the entrepreneur lives in rural areas, $81 \%$ of entrepreneurs completely agree, while $19 \%$ of entrepreneurs believe that the place of living is not important when doing a business.

7. Analysis of the representation of women entrepreneurs in rural areas shows that $98 \%$ of entrepreneurs responded negatively, while only $2 \%$ answered positively.

Rural women in Macedonia have lower levels of education than rural men, especially compared to urban women. Rural women also constitute most excluded group in the economic life of society compared to rural men or urban women / men (Center for Research and Policy, 2012).

8. The question whether there is institutional support to start own business in rural areas $10 \%$ of respondents said yes, $50 \%$ of respondents answered "no," while $40 \%$ answered "do not know".

These data point to the conclusion that the work on the institutional infrastructure to support rural entrepreneurship in the country is not sufficiently effective in the pursuit of their activity. These services do not meet the needs of rural entrepreneurs and therefore the rural areas tend not to be attractive for the entrepreneurs.

9. The question whether there are EU grants that provide support for entrepreneurial activity in rural areas, $60 \%$ responded negatively, while $40 \%$ answered "do not know". 
The main reason for this entrepreneur's attitude is a lack of public campaign for the programs of the European Union that are available to rural entrepreneurs, resulting in an ignorance of entrepreneurs for these programs. Informal conversations with entrepreneurs lead to the conclusion that entrepreneurs have no experience in applying and implementing these programs, taking into account the complexity of these programs, and actually do not know which institution to address, which one is the most appropriate.

10. The question whether you have access to affordable financing for startups in rural areas compared with those in urban ones $82 \%$ responded negatively, while $18 \%$ answered "do not know".

Although the National Programme for Agriculture and Rural Development defines the measures to support the rural development in form of direct payments, rural development, promotion and support of agricultural markets, technical support measures, the views of the surveyed entrepreneurs put at question the effectiveness of the implemented measures (Federation of farmers of the Republic of Macedonia, 2013). Entrepreneurs are not really familiar with the existence of such support measures for the development of rural entrepreneurship which leads to the conclusion that entrepreneurial activity is mainly relied on their own financial resources, not using the available favorable measures. Considering the fact that the rural area is inhabited by mostly poor population, the lack of funding is seen as an obstacle for starting entrepreneurial activity in those areas. Therefore, the lack of funding is a serious threat in the endeavor to intensify entrepreneurial activity in rural areas.

\section{RECOMMENDATIONS FOR CREATING SUSTAINABLE RURAL ENTREPRENEURSHIP IN THE REPUBLIC OF MACEDONIA}

With the previous analysis of the rural entrepreneurs attitude in terms of rural entrepreneurship in Macedonia we found out that although the rural entrepreneurship is already included in national programs and the basic principles for the development of rural entrepreneurship are being set, it is necessary to introduce new policies, measures, instruments and further increase the effectiveness of existing ones, which will lead to the creation of what is called the rural economy.

\section{a) Recommendations for strengthening rural entrepreneurship by} transforming rural areas in a favorable place to live and work.

In order to prevent the rural population migration to inland urban areas, especially to retain the young population which is a potential for development of entrepreneurial ideas, a significant workforce and at the same time a 
significant consumer, it is essential to create vitality in rural areas first by creating favorable living conditions in those areas.

The distance and high transport costs make the rural areas unattractive both for the consumers, suppliers and employees. A favorable infrastructure is particularly important for rural entrepreneurs (Stathopoulou et al., 2004).

Rural development has already been included in the Macedonian national strategic documents. Thus, the National program for agricultural and rural development for 2013-2017 as priority areas of rural development policy specifies: improvement of the life quality in rural areas, diversification of economic activities in these areas and fostering local development in rural areas.

A part of the rural development measures is funded by the national budget of the Republic of Macedonia, and part by the EU budget for the measures of Instruments for pre-accession assistance in rural development (IPARD) (Ministry of Agriculture, Forestry and Water Economy, 2012). To create a sustainable rural entrepreneurship it is essential to further increase the findings and expand the measures related to rural development in Macedonia.

In order to boost agriculture in rural areas, it is necessary for the policies that support the agriculture to be directed to (Ministry of Agriculture, Forestry and Water Economy, 2012):

- Providing a market, technology and rural infrastructure in order to increase the added value and meeting the EU standards.

- Enlargement of the agricultural production.

- Enhance cooperation between primary producers and purchasers with improved exchange of market information and production planning and purchase.

- Improved access to the factors of production.

- Improved marketing of agricultural products.

- Further adjustment measures of the Common Agricultural Policy of the European Union.

Rural tourism, together with agriculture and forestry is one of the six main areas of the Strategy for Sustainable Development of the Republic of Macedonia for the period 2009-2030. Although rural tourism is a new terminology in Macedonia and has a small part in GDP creation, the position of this sector in the long-term Strategy for sustainable development shows its strategic importance which should experience progress. In order to achieve these longterm goals it is necessary for the policymakers to focus on the following activities (Ministry of Economy of the Republic of Macedonia, 2011): 
- Improvement of road, local infrastructure.

The state of road infrastructure significantly affects the attractiveness of certain rural tourist spots and has a direct impact on both development of the rural tourism and increase in the vitality of rural areas in general.

- Introduction of informal training for rural tourism.

Tourism as a separate module is covered in several higher education institutions in Macedonia, but its massive involvement in the informal training for entrepreneurs is necessary as well. Rural tourism is usually a family business, but there is a necessity of professionalism in the management of facilities, as well as having effective marketing skills in order to increase the attractiveness of the business.

- Increasing the number of accommodation facilities for tourists in rural areas.

- Creation of a single coordinating body in Macedonia.

That body will initiate policies for tourism development in Macedonia and would lead a progressive marketing campaign for tourist destinations in Macedonia (including rural tourism). Agency for Promotion and Support of Tourism which coordinate promotional activities was established in 2008, but the Economics department of the Government of Macedonia continues to perform the policy making.

Although the agriculture and tourism emerge as a major activity in rural areas, in order to improve the quality of life in these areas and to keep the local population from a migration to urban areas it is necessary to diversify the economic activities in these areas that would include traditional craft activities, sports, cultural and other recreational activities, gathering wild plants etc.

In order to achieve the long-term goals of creating sustainable rural development, there is a particular importance of inclusion of women in economic activities in rural areas. For the time being, their role is marginalized and they are mainly involved in agricultural production for own consumption. To strengthen the role of female entrepreneurs, it is essential for the policymakers to focus on these activities (Center for Research and Policy, 2012):

- Adopting strategies for strengthening the women gender equality in rural areas.

- Consultations with rural women about the local infrastructure projects and initiatives.

- Improved access to education and informal training for rural women. 
- Support initiatives for rural women to start their own business.

- Provision of technical support to rural communities in applications for financial assistance from international donors.

- Provision of funding for rural women entrepreneurs by banks in Macedonia.

- Increased awareness of rural women to undertake entrepreneurial initiative and the need for economic independence.

\section{b) Recommendations for strengthening rural entrepreneurship by strengthening the institutional infrastructure.}

There is already established institutional structure in Macedonia to support the rural development through state organizations and institutions (Agency for Promotion of Agricultural Development, the Agency for Financial Support of Agriculture), universities and various foundations and associations.

The unused advisory and financial services of these institutions and the general ignorance among entrepreneurs, lead to the conclusion that they do not meet the needs of rural entrepreneurs and there should be taken far more structural reforms firstly to provide basic living conditions in rural areas, and then to improve the measures to support the rural entrepreneurship.

When creating the policy for institutional support of the rural entrepreneurship it is necessary to base the polices on the examples of best practices of the EU Member States, by analyzing successful practices that would be applicable in our conditions.

\section{c) Recommendations for strengthening rural entrepreneurship by improving the access to finance.}

Considering the fact that finances are serious obstacle to start a business for the majority of entrepreneurs, the policy creators must improve the access to finance for rural entrepreneurs following the EU directives and the best practices and experiences in this regard. For this purpose, first, it is necessary to create a developed capital market, which will be integrated into the international capital flows, with developed financial system supported by a number of commercial, investment and development banks, then to specialized financial institutions for SME support sector. A development of micro-finance for rural entrepreneurs is especially important, because the most established enterprises in rural areas are the micro ones.

For the Republic of Macedonia it is particularly important to accelerate the EU integration process. Apart from the utmost importance for the economy in 
general, the EU integration will also increase the Macedonian rural entrepreneurs' access to the European money.

\section{CONCLUSION}

Based on the studies on the importance of rural entrepreneurship, the current situation of rural areas in Macedonia and the attitudes of entrepreneurs to start businesses in rural areas, based on theoretical research as well as our own research and practical findings about the needs of the paper, we concluded that rural areas in Macedonia have rich natural resources. However, they are underutilized and poorly transferred into a business activity which will accelerate the economic development in rural areas.

Although there is an awareness among the national authorities about the importance of the development of rural areas, it is necessary to create the future policies, measures and programs in direction first to increase the vitality of rural areas and retention of the rural population and then to create policy for rural entrepreneurship development.

The results of the research and the survey regarding the attitude of entrepreneurs starting a business in rural areas in Macedonia represent a rich source of information, whose analysis provides a realistic perception of the business environment in rural areas in Macedonia. The analysis in the paper enables recognition of the need for change, further completion and upgrading the necessary conditions for creating stimulative rural entrepreneurial environment. In this term it is particularly important to research the experiences and best practices of the EU countries, the measures and instruments that would be applicable to us. The transfer of experiences and knowledge from developed European countries can serve as a scientific base for profiling policy support for rural entrepreneurship in Macedonia.

\section{REFERENCES}

Centre for research and policy creation. (2012). Perspectives of women in rural areas. (pp. 127-134).

Dabson, B. (2001). Suporting Rural Entrepreneurship. In Federal Reserve Bank of Kansas City Proceedings. (pp. 35-47). 27.

Federation of farmers in the Republic of Macedonia. (2013). Rural economy.

Law on Agriculture and Rural development. Official Gazette of the Republic of Macedonia, (2010). 49. 
Ministry for agriculture, forestry and water economy of the Republic of Macedonia. (2015). Instrument for Pre-accession Assistance of EU (IPA) Program for rural development 2014-2020.

Ministry for agriculture, forestry and water economy of the Republic of Macedonia. (2012). National Programme for agricultural and rural development for period 2013-2017.

Ministry for economy of the Republic of Macedonia. (2011). National Strategy for Rural Development 2012-2017.

Smallbone, D., \& Welter, F. (2006). Conceptualising entrepreneurship in a transition context. International Journal of Entrepreneurship and small business, 3(2), 190-206.

Stathopoulou, S., Psaltopoulos, D., \& Skuras, D. (2004). Rural entrepreneurship in Europe: A research framework and agenda. International Journal of Entrepreneurial Behaviour \& Research, 10(6), 404-425.

World Bank. (2016). Population growth, Rural population growth, Urban population growth (\% of total population). Retrieved from http://databank.worldbank.org/data/reports.aspx?source=2\&series

World Bank. (2016). Rural population (\% of total population). Retrieved from http://data.worldbank.org/indicator/SP.RUR.TOTL.ZS?end=2015\&locati ons $=$ MK\&start $=1960 \&$ view $=$ chart

\section{APPENDIX}

\section{QUESTIONNAIRE}

1. Do you prefer to operate your own business in urban areas or rural ones?

a) Urban area

b) Rural area

2. According to you what are the most common businesses that are managed in rural areas?

3. What are for you the most important decisive factors that would affect your decision to start a business in a rural area in Macedonia? 
4. If you start your own business in a rural area in Macedonia do you think the locals will be qualified enough to hire?
a) Yes
b) No

5. Do you think that Macedonia has enough local resources would be sufficient for rural entrepreneurship development?

a) Yes

b) No

6. Do you think that business will be more successful if the entrepreneur lives in the rural area?
a) Yes, absolutely
b) No

7. Are women entrepreneurs represented in rural areas in Macedonia?
a) Yes
b) No

8. Is there an institutional support to start own business in rural areas?
a) Yes
b) No
c) Do not know

9. Are there grants from international institutions for the development of entrepreneural activity in Macedonia?
a) Yes
b) No

10. Do banks in Macedonia offer favorable funding for start-ups in rural areas?
a) Yes
b) Do not know

Primljeno: 20.09.2016.

Odobreno: 15.12.2016. 


\title{
UTICAJ ANIMACIJE NA DUŽINU TRAJANJA I RADIJUS IZLETNIČKO-REKREATIVNIH KRETANJA
}

\author{
Dragana Dimitric ", Prirodno-matematički fakultet, Departman za geografiju, \\ turizam i hotelijerstvo, Novi Sad \\ Aleksandra Vujko, Visoka poslovna škola strukovnih studija, Novi Sad \\ Tamara Gajić, Visoka poslovna škola strukovnih studija, Novi Sad \\ Marko Petrović, Geografski institut "Jovan Cvijić” SANU, Beograd
}

Sažetak: Osnovna hipoteza od koje se krenulo u radu jeste tvrdnja da animacija posetilaca direktno utiče na dužinu trajanja i radijus izletničko-rekreativnih kretanja u turizmu. Osnovni cilj istraživanja predstavlja definisanje uticaja animacije na izbor izletničko-rekreativnih destinacija, a samim tim $i$ na dužinu trajanja i radijus kretanja turista. Na prostoru Grada Beograda postoji više zaštićenih prirodnih dobara, a jedno od njh je Veliko ratno ostrvo pri ušću Save u Dunav. Ovaj prostor funkcioniše u okviru tri zaštićene zone. Predmet anketiranja su bili privremeni stanovnici koji žive u jednoj od ovih zona, kao i Udruženje turističkih vodiča Srbije. Došlo se do zaključka da je jedna od najvećih prednosti razvoja turizma na Velikom ratnom ostrvu upravo mogućnost razvoja određenih oblika turizma, od kojih izletničko-rekreativni turizam ima višestruke pozitivne efekte na stanovništvo koje ga upražnjava. Isto tako, u radu se došlo do zaključka da animacija direktno srazmerno utiče na dužinu trajanja boravka turista na destinaciji, kao i na radijus njihovih kretanja.

Ključne reči: animacija, izletničko-rekreativni turizam, Veliko ratno ostrvo, Beograd

\section{THE IMPACT OF ANIMATION ON THE LENGTH OF STAY AND RADIUS OF MOVEMENT OF THE EXCURSION-RECREATIONAL TOURISM}

Abstract: The basic hypothesis from which we started in the paper is the claim that animation of visitors has a direct impact on the length and radius of excursionrecreational tourism. The main objective of the research is to define the role of

*sadranel@gmail.com 
animation in the choice of tourist detination and length of staying. In the area of the City of Belgrade, there are more protected natural areas and one of them is the Great War Island located at the confluence of the River Sava in River Danube. This area has three protected zones. Temporary population that was the subject of the interview, as well as the Association of Tourist Guides of Serbia occupate one of these zones. We concluded that one of the biggest advantages of developing tourism of the Great War Island is the possibility of developing certain forms of tourism, and one of these forms, the excursion-recreational tourism has multiple positive effects on the population. The paper concluded that the animation proportionally affects the length of stay of tourists, as well as the radius of their movement.

Key words: animation, excursion-recreational tourism, The Great War Island, Belgrade

JEL Classification: Z32

\section{UVOD}

Animacija u turizmu se pre svega odnosi na uspostavljanje najbližih relacionih odnosa između domaćina i gostiju, a s obzirom na to da u turističkim kretanjima učestvuje istovremeno mnogo posetilaca sa različitih podneblja, preko je potreban posrednik između njih radi lakšeg razumevanja i međusobnog druženja, ali takođe, neko ko će na pravi način prezentovati destinaciju i zbog koga će na samoj destinaciji biti više posetilaca (Gajić, 2009). Može se reći da vizuelni prostor igra bitnu ulogu kao stimulaciono sredstvo za goste, ali osim vizuelne funkcije i atrakcija na samoj destinaciji, postoji i jedna neizostavna funkcija koja se provlači tokom celokupnog rada i aktivnosti animatora, a to je gostoljubivost $\mathrm{u}$ radu sa turistima i spremnost na sve dodatne zahteve turista $\mathrm{u}$ animacionim projektima (Gajić, 2009). Postoji jedna bitna činjenica i zadatak koji ne sme da se zaboravi i ostavi po strani, a to je da animatori koji održavaju svoje programe u prirodnim ambijentima moraju da vode računa da se prirodni resursi ne uništavaju. Na taj način će pozitivno uticati na razvoj svesti o ekološkoj zaštiti i značaju prirode kod posetilaca. Znači, zamisao animatora treba da bude usmerena ka ekološkim zahtevima i pozitivnim aspektima u interaktivnom odnosu turizam-ekologija.

Prema Vukoniću i Čavleku (2001), izletima se smatraju putovanja koja se odvijaju vikendom, što znači da mogu uključivati i jedno do dva noćenja. U tom smislu se razlikuju poludnevni, dnevni i vikend izleti, a u osnovi predstavljaju kraća putovanja sa zabavnom, sportsko-rekreativnom, kulturnom ili naučnom svrhom. Ako bismo se nadovezali na prethodnu konstataciju, koja o izletu govori kao o kraćem putovanju ili kretanju, može se zaključiti da izletničko mesto ne sme da bude mnogo udaljeno od matičnog mesta boravka izletnika. ŠKOLA BIZNISA, 2/2016, $29-37$ 
Prirodno dobro "Veliko ratno ostrvo", zaštićeno 2005. godine, nalazi se na teritoriji Beograda, gradska opština Zemun i sastoji se od dve rečne ade, Velikog (210,66 hektara) i Malog ratnog ostrva (0,75 hektara), koje su smeštene između 1172. i 1169. kilometra toka Dunava, sa zaštitnim pojasom u širini od 50 metara vodene površine. Zaštićeno prirodno dobro čini i svaka druga površina tla Velikog i Malog ratnog ostrva koja se, pri najnižem stanju vodostaja, nalazi iznad nivoa reke, kao i svi sprudovi koji povremeno nastaju. Ukupna površina zaštićenog prirodnog dobra iznosi 211,38 hektara (Zaštićena prirodna dobra, 2008).

Prvi zabeleženi naziv je Dunavsko ostrvo. U jednom periodu egzistira pod imenom Cigansko ostrvo, pa Sirotinjsko, da bi današnje ime dobilo za vreme operacije zauzimanja Beograda, koju je izvela austrijska vojska pod komandom Evgenija Savojskog 1719. godine. Od tada se redovno pojavljuje na svim vedutama, kartama, planovima i drugim dokumentima, vojnim i civilnim. Od samog nastanka ostrvo je bilo strateški značajno za vojne operacije, a u 19. veku veku postaje i važna raskrsnica trgovačkih puteva. Veliko ratno ostrvo, u kompoziciji sa vrednim nasleđem Beogradske tvrđave, starim jezgrom Zemuna i kulom Gardoš, predstavlja neobičnu i bogatu celinu prirodnog i kulturnoistorijskog nasleđa Beograda (Zaštićena prirodna dobra, 2008).

Predmet istraživanja je Veliko ratno ostrvo u Beogradu kao prepoznatljiva izletničko-rekreativna destinacija i jedno od omiljenih turističkih zona Beograda, koje posećuju kako domaći, tako i strani gosti. Osnovni cilj ovog istraživanja bio je da se pokaže uticaj animacije na izbor turističke destinacije, odnosno radijus kretanja, kao i dužinu trajanja turističkih kretanja. U radu je korišćena tehnika anketiranja kao način prikupljanja podataka na terenu. Dobijeni rezultati su ukazali na neke od ključnih problema i nedostataka u ovom segmentu, a takođe su date osnovne smernice za prevazilaženje uočenih nedostataka.

\section{METODOLOGIJA}

Prostor Velikog ratnog ostrva funkcioniše u okviru tri zaštićene zone. U jednoj od ovih zona žive privremeni stanovnici koji su učestvovali u anonimnoj anketi. Cilj anketiranja je bio da se utvrdi starosna, polna i obrazovna struktura privremenih stanovnika Velikog ratnog ostrva, njihov motiv dolaska na ostrvo, kao i njihovo poznavanje prostora na kojem žive više od polovine godine. Kao i na svakom prostoru, tako i na ovom postoje određeni problemi, kao i prednosti. Jedna od najvećih prednosti jeste mogućnost razvoja određenih oblika turizma, od kojih izletničko-rekreativni turizam ne ugrožava prostor u kojem se odvija, a 
ima višestruke pozitivne efekte na stanovništvo koje ga upražnjava. Tako se dolazi do polazne hipoteze koja glasi: Stanovništvo velikih gradova ima svoje izletničko-rekreativne zone koje koristi, ali dužina boravka na destinaciji, kao i sam radijus kretanja, direktno zavise od animacije. Unutar ove hipoteze mogu se izdvojiti tri pothipoteze:

- izlazak stanovništva $\mathrm{u}$ izletničko-rekreativne prostore ima pozitivan zdravstveni efekat (hipoteza 1).

- ako se u prirodne oaze odlazi tokom više meseci u godini, tada se pozitivni efekti istog mogu dugoročno osetiti (hipoteza 2).

- najviše stanovništva koje dolazi na prostor Velikog ratnog ostrva je iz obližnjih opština, odnosno opštine Zemun (hipoteza 3).

Istraživanje za ovaj rad vršeno je pretežno na terenu kroz posetu objektima i razgovore sa stručnim licima, a informacije su prikupljane i iz različitih stručnih radova i publikacija. Krajem avgusta 2013. godine u razgovoru sa predstavnicima JKP "Gradsko zelenilo" koje održava Veliko ratno ostrvo došlo se do sledećih podataka:

- Ukupan broj sojenica je 36, od kojih je 4 ili 5 ruinirano, ali se, bez obzira na to, sve koriste;

- Privremeni stanovnici borave na ostrvu od proleća do jeseni (najčešće dolaze u proleće kad opadne nivo reke koja poplavi celo ostrvo i ostaju do kasno u jesen);

- Na ostrvu postoje tri režima zaštite;

- Ukoliko se radi neko istraživanje ili se radi o organizovanim grupama, potrebno je prethodno najavljivanje, a pri tom postoji pratnja koja će provesti posetioce kroz dozvoljene zone ostrva.

Krajem avgusta iste godine urađena je i anonimna anketa na Velikom ratnom ostrvu. Njom je obuhvaćeno 10 privremenih stanovnika sojenica. Anketa je urađena u jednom danu na stanovnicima koji su tog dana boravili na ostrvu. Privremeni stanovnici su odgovarali na sedamnaest pitanja grupisanih u dve grupe. Prva grupa pitanja je obuhvatila opšte podatke o anketiranima (prvih pet pitanja), a druga grupa pitanja je ciljano postavljena za tematiku ostrva. Niko nije odbio da popuni anketu. Od deset anketiranih, njih 6 su stanovnici opštine Zemun, 2 je sa Vračara, 1 je sa Novog Beograda i 1 je iz opštine Stari grad. Ovi podaci pokazuju da su privremeni stanovnici većinom iz beogradske opštine Zemun i to $60 \%$, što se moglo i očekivati s obzirom na blizinu Velikog ratnog ostrva, te je ovim dokazana pothipoteza 3. 

AKTIVNOSTI

Godine 2015. u toku letnjih meseci, sprovedeno je i anketno istraživanje pomoću ankete sa skaliranim pitanjima zatvorenog tipa na uzorku od 27 ispitanika, turističkih vodiča Udruženja turističkih vodiča Srbije. Njima su postavljena dva pitanja: da li smatraju da animacija utiče na izbor destinacije i da li animacija utiče na dužinu doravka turista na destinaciji.

\section{REZULTATI I DISKUSIJA}

$\mathrm{Na}$ Velikom ratnom ostrvu privremeni stanovnici koji su učestvovali u anketi prosečne su starosti 73,6 godina. Ovaj podatak ukazuje da stanovništvo Velikog ratnog ostrva pripada stanovništvu "treće dobi". Iako su stanovnici ove prosečne starosti, svi oni deluju veoma vitalno, što se može povezati upravo sa načinom života koji vode. To podrazumeva da nešto više od polovine godine koju provedu u ovoj oazi mira pomalo obrađuju zemljište, te se na taj način bave i fizičkom aktivnošću. Takođe, ono što oni jedu, to i proizvedu upravo u samoj blizini svojih sojenica (oko polovine se bavi obradom zemljišta i imaju sopstvene manje voćnjake). Ako se pogleda tabela 1. može se primetiti da je njih sedmoro starosti preko 70 godina, što čini $70 \%$ ukupnog broja privremenih stanovnika Velikog ratnog ostrva. Najstariji privremeni stanovnik ima 80 godina. Ovim su dokazane pothipoteze 1 i 2.

Tabela 1

Starosna struktura privremenih stanovnika Velikog ratnog ostrva

\begin{tabular}{|c|c|c|}
\hline $50-60$ godina & $61-70$ godina & 71 - 80 godina \\
\hline 1 & 2 & 7 \\
\hline 58 god. & 68 и 67 god. & $78,80,78,79,74,77,77$ god. \\
\hline
\end{tabular}

Napomena. Proračun autora.

Što se tiče stručne spreme, to su uglavnom visokoobrazovani ljudi. Tabela 2 prikazuje njihovu obrazovnu strukturu. Među anketiranima je bio i jedan magistar nauka.

Tabela 2

Obrazovna struktura privremenih stanovnika Velikog ratnog ostrva

\begin{tabular}{|l|l|l|l|l|}
\hline Stručna sprema & Srednja & Viša/Visoka & Fakultet & Mr/Dr \\
\hline Broj & 3 & 5 & 1 & 1 \\
\hline
\end{tabular}

Napomena. Proračun autora. 
Tabela 2 pokazuje da je $70 \%$ privremenog stanovništva visokoobrazovano, a ostatak od 30\% ima srednju stručnu spremu. Ovaj podatak može da ukaže na dva razloga zašto je ovoliko visok procenat visokoobrazovanih izabrao da ima sojenice na Velikom ratnom ostrvu i da u njima živi. Prvi razlog je da su ovi ljudi na visokom nivou svesti, te su se zbog svog zdravlja, uživanja i sličnog odlučili na ovaj vid života, a drugi razlog je potpuno suprotan, te su na Velikom ratnom ostrvu iz egzistencijalnih razloga. Ako se uzme u obzir da su to stariji ljudi, a shodno tome su i svi penzioneri $(100 \%)$, kako je anketa potvrdila, dolazi se do zaključka da je veća verovatnoća da su ovi ljudi na ovom prostoru iz prvog navedenog razloga.

Na pitanje da li posećuju Veliko ratno ostrvo redovno svake godine ili to rade samo ponekad, svih deset (100\%) je odgovorilo da redovno posećuju ostrvo. Interesantni su odgovori anketiranih da jedan od njih dolazi na ostrvo već 70 godina, njih troje dolaze 30 godina, njih dvoje dolaze 28 godina, a i ostali dolaze takođe već veoma dugo. Ovi podaci prikazani su u tabeli 3 . Dugogodišnji dolasci na ostrvo imaju pozitivne efekte na zdravlje, a kao što se može videti iz tabele 1. prosečna starost privremene populacije je 73,6 godina, čime su dokazane pothipoteze 1 i 2.

Tabela 3

Koliko godina privremeno stanovništvo Velikog ratnog ostrva dolazi na ostrvo

\begin{tabular}{|l|c|c|c|c|c|c|c|}
\hline Godina & $\mathbf{7 0}$ & $\mathbf{3 0}$ & $\mathbf{2 8}$ & $\mathbf{2 4}$ & $\mathbf{2 3}$ & $\mathbf{1 5}$ & $\mathbf{8}$ \\
\hline Stanovništvo & 1 & 3 & 2 & 1 & 1 & 1 & 1 \\
\hline
\end{tabular}

Napomena. Proračun autora.

Da bi se prevezli do Velikog ratnog ostrva, njih 10 koristi čamac, pri čemu je njih troje odgovorilo da imaju sopstveni čamac. Kada je postavljen pontonski most u julu 2015. godine, posetioci su mogli da se zadrže na ostrvu do 20 časova. Prema podacima JKP "Gradsko zelenilo", to su bili pretežno posetioci plaže Lido, odnosno predstavnici kupališnog turizma. Međutim, bilo je i izletnika koji su došli da prošetaju po Velikom ratnom ostrvu. Po procenama, u julu 2015. godine bilo je više od 50.000 posetilaca. Pontonski most se ne postavlja svake godine. Da li će se pontonski most postaviti ili ne, zavisi isključivo od nivoa reke. Kada pontonski most nije postavljen, ostrvo je dostupno jedino putem čamaca. U toku 2015. godine pontonski most je bio postavljen od 30. juna do 30. avgusta.

Privremeni stanovnici Velikog ratnog ostrva dolaze na ostrvo najviše sa članovima porodice, njih 9 (ili $75 \%$ ), a sa prijateljima dolazi njih 3, ostatak od $25 \%$. Primećuje se da je ukupan broj odgovora veći od 10, koliko je anketiranih. 

AKTIVNOSTI

Razlog tome je što su anketirani mogli da se odluče za više odgovora. Kao motiv dolaska na Veliko ratno ostrvo njih 6 je navelo da ovde žive povremeno, a takođe njih 6 je izjavilo da se bave poljoprivredom. Njih dvoje na ostrvo dolaze i zbog rekreacije. S obzirom da je većina znala koliko vrsta ptica ima na ostrvu i znala je da navede neku od njih (9 znalo odgovor, a 1 nije), i takođe su znali koja to biljna vrsta ugrožava floru ostrva ( 8 znalo odgovor, a 2 nije), zaključuje se da privremeni stanovnici poznaju ostrvo na koje dolaze. Takođe, odgovori na sledeća dva postavljena pitanja ukazuju na prethodno iskazan zaključak. Na pitanje "Koji status ima ostrvo?", njih 6 je odgovorilo da je to ostrvo zaštićeno prirodno dobro, 2 da je ostrvo zaštićeno, 1 da je ono zaštićena zona i 1 da je ostrvo prirodno dobro izuzetnih vrednosti. Svih 10 učesnika ankete odgovorilo je da je staratelj na Velikom ratnom ostrvu JKP "Gradsko zelenilo". Na pitanje "Koliko ima režima zaštite na ostrvu?", četvoro anketiranih je znalo odgovor da postoje tri režima zaštite, troje nije znalo, dvoje je smatralo da ih nema, a jedan anketirani nije bio siguran.

Odgovori na pitanje "Šta biste promenili i čime biste upotpunili ponudu Velikog ratnog ostrva?" prikazani su u tabelarnom prikazu sa tačnim navodima odgovora na njega (Tabela 4).

Tabela 4

\section{Predlozi za promene i upotpunjavanje ponude Velikog ratnog ostrva}

\begin{tabular}{|l|}
$\begin{array}{l}\text { Šta biste promenili i čime biste upotpunili ponudu Velikog ratnog } \\
\text { ostrva? }\end{array}$ \\
\hline Ne dozvoliti uznemiravanje flore i faune (koncerti mladih) \\
\hline Ništa ne treba da se menja \\
\hline $\begin{array}{l}\text { Pojedini drže živinu, zečeve, ćurke, a sva ta živina stvara vrlo jak smrad, pa } \\
\text { turisti i posetioci izbegavaju da obilaze ostrvo }\end{array}$ \\
\hline Most, voda za piće \\
\hline Bolje održavanje \\
\hline $\begin{array}{l}\text { Veći angažman gradskih zvaničnika i više promotivnih aktivnosti i } \\
\text { animacije i obavezno svake godine uspostavljanje pontonskog mosta }\end{array}$ \\
\hline Uređenje plaže \\
\hline
\end{tabular}

Napomena. Proračun autora.

Interesantno je da je svih 27 ispitanika (100\%), turističkih vodiča iz Udruženja turističkih vodiča Srbije, odgovorilo da smatraju da animacija utiče na izbor 
destinacije, u ovom slučaju na izbor da li doći ili ne na Veliko ratno ostrvo, kao i to da animacija direktno utiče na dužinu boravka turista na destinaciji. Što je destinacija bolje promovisana, a na njoj radi obučeni stručni kadar, turisti će duže ostajati na destinaciji i rado će se na nju vraćati (Vujko, Vujnić, Gajić i Petrović, 2016). Sve ovo je dokazalo polaznu hipotezu H da stanovništvo velikih gradova ima svoje izletničko-rekreativne zone koje koristi, a da dužina boravka na destinaciji, kao i sam radijus kretanja, direktno zavise od animacije.

\section{ZAKLJUČAK}

Jedan od najvećih bisera grada Beograda je Veliko ratno ostrvo, pravi raj za izletnike, rekreativce, ljubitelje ptica i sve druge koji vole očuvanu prirodu. Međutim, ono što je značajno, a uistinu interesantno, jeste da se ovaj prostor nalazi usred urbanog Beograda i samim tim ga čini još više jedinstvenim prostorom.

$\mathrm{Na}$ Velikom ratnom ostrvu danas ima vikendica - sojenica i bašta zaljubljenika u prirodu, a na gornjem špicu Velikog ratnog ostrva nalazi se omiljena zemunska plaža Lido. Međutim, polazeći od već pomenutih karakteristika, prirodno dobro „Veliko ratno ostrvo” zaštićeno je kao predeo izuzetnih odlika koji brine o staništu retkih i ugroženih ptica močvarica, a zaštita je ustanovljena radi očuvanja reprezentativne morfološke i geološke tvorevine, rečnog ostrva nastalog na ušću Save u Dunav, koje ima kulturno-istorijski i izletničkorekreativni značaj za stanovnike Beograda. Zaštićeno prirodno dobro „Veliko ratno ostrvo" kategorisano je kao značajno prirodno dobro, u okviru kojeg su utvrđene tri zone sa različitim režimom zaštite.

Pored ovih režima zaštite, na zaštićeno prirodno dobro primenjuju se režimi zaštite utvrđeni zakonom i drugim propisima kojima se utvrđuje upravljanje međunarodnim plovnim putevima, zaštita vodosnabdevanja i vodoprivrednih objekata, zaštita močvarnih područja, kao i zaštita lovnih i ribolovnih rezervata (Čomić, 2003; Zaštićena prirodna dobra, 2008). Da bi se uživalo u izletničkorekreativnom turizmu, kao i drugim oblicima turizma na ovom prostoru, nije potrebno dodatno uređivanje prostora, zato što bi se na taj način ugrozile zaštićene zone. Međutim, trebalo bi još više ovaj prostor približiti i ostalom stanovništvu iz ostalih opština grada Beograda, jer kako se iz ovog istraživanja vidi, najviše stanovnišva koje koristi i uživa blagodeti ovog prostoru jesu iz obližnje opštine Zemun. Treba razmisliti i o mogućnostima približavanja ovog prostora mlađim populacijama, a u okviru izletničko-rekreativnog turizma, na primer otvaranjem jednog mini zoološkog vrta sa životinjama sa ovog ostrva (naročito ptica, riba i vodozemaca) koje se trenutno na ostrvu mogu videti pretežno na izloženim panoima. Ovakav zoološki vrt bi privukao i šire mase. Mogućnost obilaska ostrva na magarcima ili kočijom ulepšali bi prikaz ovog ŠKOLA BIZNISA, 2/2016, $29-37$ 
ostrva. Na taj način bi ovaj vid turizma imao i određeni finansijski efekat (Vujko, Gajić i Kovačević, 2012; Penić, Dragosavac, Vujko i Besermenji, 2016). Ovde bi se takođe mogli razmotriti i drugi predlozi koji bi nadopunili ponudu skrivenog ostrva usred grada Beograda.

\section{REFERENCE}

Boris, V., \& Čavlek, N. (2001). Rječnik turizma. Zagreb: Masmedija.

Čomić, Đ. (2003). Prostorno-planski modeli razmeštaja turizma u ruralnoj sredini. U: Zbornik radova sa skupa Ruralni turizam i održivi razvoj Balkana, Kragujevac.

Gajić, T. (2009). Osnovne karakteristike i suština animacionih aktivnosti u turizmu. Škola biznisa, 1, 78-83.

Zaštićena prirodna dobra. (2008). Beograd: Sekretarijat za zaštitu prirode Srbije - Grad Beograd - Gradska uprava. Monografija.

Penić, M., Dragosavac, M., Vujko, A., \& Besermenji, S. (2016). Impact of active tourism on economic development - The Fruška Gora National park (North Serbia). Geographica Pannonica, 20(3), 181-190.

Vujko, A., Vujnić, J., Gajić, T., \& Petrović, M. (2016). Kvalitet usluga u turističkim preduzećima kao model upravljanja turističkom destinacijom. Škola biznisa, 1, 22-31.

Vujko, A., Gajić, T., \& Kovačević, B. (2012). Turizam u zaštićenim prirodnim prostorima - ekoturizam Fruške gore. Škola biznisa, 4, 8-16.

Napomena: Rad je podržan od strane republičkog projekta III 47007, finansiranog od strane Ministarstva prosvete, nauke i tehnološkog razvoja Republike Srbije. Anketiranje je rađeno u okviru projekta XX-01 4011-450, finansiranog od strane Sekretarijata za sport i omladinu Grada Beograda i projekta XXV-01 4011-2S, finansiranog od strane Kancelarije za mlade Grada Beograda.

Primljeno: 14.11 .2016$.

Odobreno: 26.12.2016. 